\title{
Pengembangan Model Pembelajaran IPA SD Berbasis Bahan Di Lingkungan Sekitar Melalui Pendekatan Starter Eksperimen
}

\author{
Muharram, Hamka Lodang, Nurhayati, Munir Tanrere \\ Dosen FMIPA UNM Makassar
}

\begin{abstract}
Abstrak: Penelitian ini termasuk jenis penelitian pengembangan (Research and Development) yang dilakukan melalui empat tahap yang dikenal dengan "Four-D Model" yaitu define, design, develop, and disseminate. Penelitian ini bertujuan untuk menghasilkan model pembelajaran berbasis bahan-bahan di lingkungan sekitar serta perangkat pembelajaran yang meliputi, Panduan Eksperimen, Lembar Kerja Siswa, dan Alat Evaluasi. Luaran penelitian adalah sintaks model pembelajaran 6 langkah dan perangkat pembelajaran berupa tiga buah buku suplemen IPA SD dengan judul "Terampil Sains" untuk kelas 4, 5, dan 6. Hasil validasi model dan perangkat pembelajaran oleh tim akhli menunjukkan bahwa model dan perangkat pembelajaran termasuk katagori valid dengan persentasi validitas masing-masing: $88,40 \%$ dan $84,66 \%$. Hasil ujicoba melalui penelitian pra eksperimen menunjukkan bahwa: 1) model dan perangkat pembelajaran digunakan dengan baik oleh guru dan siswa; 2) penerapan model pembelajaran akan meningkatkan aktivitas, minat dan sikap ilmiah, keterampilan proses sains, dan hasil belajar siswa.
\end{abstract}

Kata kunci: penelitian pengembangan, starter eksperimen, lingkungan sekitar, dan IPA SD

\begin{abstract}
This study is a research and development that was conducted through four steps and is mentioned as a "Four-D Model", namely define, design, develop and disseminate. The aim of this research is to produce instructional model, that is a starter experiment based on environmental materials and supporting of instructional model, including: experiment guidance, student worksheet and instrument of evaluation. The product of this research is the syntax of instructional model that consist of six steps and supporting of the model, namely three supplement books for Elementary School. The titles of the books are "Science Skill" for $4^{\text {th }}, 5^{\text {th }}$, and $6^{\text {th }}$ Grade". The instructional model and its supporting were validated by expert's team and they were categorized in valid that are $88.40 \%$ for instructional model and $84.66 \%$ for the supporting of the instructional model. Try out result that conducted through the pre-experiment results showed that: 1 ) the instructional model and its supporting could be used by both the teacher and the student; 2) Apply the model and its supporting increase the activity, interest, scientific attitude, skill of science process, and the student's achievement.
\end{abstract}

Key words: Research and development, starter experiment, environmental materials, science, for elementary school.

\section{Pendahuluan}

Implementasi pendidikan IPA di Indonesia, termasuk di Sulawesi Selatan, masih rendah, hal ini dapat dilihat dari hasil literasi IPA anak-anak Indonesia. Literasi sains/IPA (scientific literacy) ditandai dengan kerja ilmiah, dan tiga dimensi besar literasi sains yang ditetapkan oleh PISA, yaitu konten IPA, proses IPA, dan konteks IPA. Hasil penelitian PISA (the Programme for International Student Assessment) tahun 2000 dan tahun 2003 menunjukkan bahwa literasi sains anak-anak Indonesia usia 15 tahun masingmasing berada pada peringkat ke 38 dari 41 negara dan peringkat ke 38 dari 40 negara. Adapun skor rata-rata pencapaian siswa ditetapkan sekitar nilai 500 dengan simpangan baku 100 point. Hal ini disebabkan kira-kira dua per tiga siswa di negara-negara peserta memperoleh skor antara 400 dan 600 pada PISA 2003. Ini artinya skor yang dicapai oleh siswa-siswa Indonesia kurang lebih terletak di sekitar angka 400. Survei juga telah dilakukan oleh TIMSS terhadap pencapaian sains anak kelas 4 (9 tahun saat di tes) dan kelas 8 (13 tahun saat di tes) dengan ruang lingkup domain konten dan domain kognitif, untuk domain konten dibedakan: level kelas 4 
mencakup Life Science, Physical Science, dan Earth Science. Domain kognitif mencakup pengetahuan tentang fakta (factual knowledge), pemahaman konsep (conceptual understanding), serta penalaran dan analisis (reasoning \& analysis). Survai TIMSS menunjukkan bahwa dari 38 negara yang berpartisipasi pada tahun 1999 dan dari 46 negara yang berpartisipasi pada tahun 2003, masing-masing anak Indonesia menempati peringkat 32 dan 37 . Skor rata-rata perolehan anak Indonesia untuk IPA mencapai 420,221, skor ini tergolong ke dalam katagori low bencmark artinya siswa baru mengenal beberapa konsep mendasar dalam Fisika dan Biologi (Rustaman: 2006 dalam Puskur Depdiknas: 2006). Ini artinya bahwa siswa-siswa Indonesia baru mampu mengingat pengetahuan ilmiah berdasarkan fakta sederhana. Hasil penelitian ini menunjukkan proses pembelajaran selama ini masih terlalu berorientasi terhadap penguasaan teori dan hafalan yang menyebabkan kemampuan belajar peserta didik menjadi terhambat. Metode pembelajaran yang terlalu berorientasi kepada guru (teacher centered) cenderung mengabaikan hak-hak dan kebutuhan, serta pertumbuhan dan perkembangan anak, sehingga proses pembelajaran yang menyenangkan, mengasyikkan, dan mencerdaskan kurang optimal.

Kurikulum tingkat satuan pendidikan (KTSP) tahun 2006 diharapkan dapat membantu mempersiapkan peserta didik menghadapi tantangan di masa depan. Standar kompetensi dan kompetensi dasar diarahkan untuk memberikan keterampilan dan keahlian bertahan hidup dalam kondisi yang penuh dengan berbagai perubahan, persaingan, ketidakpastian, dan kerumitan dalam kehidupan. Proses pembelajaran menekankan pada pemberian pengalaman langsung, kontekstual dan berpusat kepada siswa, sedangkan guru bertindak sebagai fasilitator.

Dalam silabus mata pelajaran IPA SD terlihat bahwa siswa kelas $1-6$, masih minim sekali diperkenalkan kerja ilmiah, padahal ini merupakan ciri penting pada mata pembelajaran IPA. Pada latar belakang kurikulum mata pelajaran IPA siswa kelas 1 - 6 sebenarnya telah disebutkan bahwa: "Pembelajaran IPA sebaiknya secara inkuiri ilmiah (scientific inquiry) untuk menumbuhkan kemampuan berpikir, bekerja dan bersikap ilmiah serta mengkomunikasikannya sebagai aspek penting kecakapan hidup" (Puskur Depdiknas: 2006). Hal tersebut terlihat pada Standar Kompetensi dan Kompetensi Dasar untuk kurikulum 2006 pada mata pelajaran IPA SD, adalah sebagai berikut: 1) siswa kelas 1 - 3, belum diperkenalkan pada kerja ilmiah, mereka masih terbatas pada: mengenal, mengidentifikasi, membiasakan, membedakan, menggolongkan, mendeskripsikan; 2) siswa kelas 4 semester 2, baru mulai diperkenalkan dengan kerja ilmiah, yaitu menyimpulkan hasil percobaan bahwa gaya (dorongan dan tarikan) dapat merubah gerak suatu benda dan dapat mengubah bentuk suatu benda; 3) siswa kelas 5, nampak adanya kerja ilmiah yaitu menyimpulkan hasil penyelidikan tentang perubahan sifat benda, baik sementara maupun tetap, tetapi sebagian besar hanya mengidentifikasi dan mendeskripsikan; 4) siswa kelas 6, nampak juga adanya kerja ilmiah, yaitu melakukan percobaan untuk menyelidiki hubungan antara gaya dan gerak. Dari uraian ini, terlihat bahwa siswa kelas $1-6$, masih minim sekali diper-kenalkan kerja ilmiah, padahal ini merupakan ciri penting pada mata pembelajaran IPA. Pada latar belakang kurikulum mata pelajaran IPA siswa kelas 1 - 6 sebenarnya telah disebutkan bahwa: "Pembelajaran IPA sebaiknya secara inkuiri ilmiah (scientific inquiry) untuk menumbuhkan kemampuan berpikir, bekerja dan bersikap ilmiah serta mengkomunikasikannya sebagai aspek penting kecakapan hidup" (Puskur Depdiknas: 2006). Dengan minimnya pembelajaran IPA dengan kerja ilmiah tersebut berarti sikap ilmiah juga menjadi minim.

Berdasarkan hal di atas, maka pembelajaran IPA SD seharusnya ditingkatkan dengan melakukan: 1) pembelajaran IPA tidak hanya pembelajaran konsep-konsepnya saja, namun juga disertai dengan pengembangan sikap dan keterampilan ilmiah (domain pengetahuan dan proses kognitif); 2) pembelajaran IPA memberikan pengalaman belajar yang mengembangkan kemampuan bernalar, merencanakan dan melakukan penyelidikan ilmiah, menggunakan pengetahuan yang sudah dipelajari untuk memahami gejala alam yang terjadi di sekitarnya; 3) merevitalisasi "keterampilan proses sains" untuk mengembangkan kemampuan observasi, merencanakan penyelidikan, menafsirkan 
(interpretasi) data dan informasi (narasi, gambar, bagan, tabel) serta menarik kesimpulan

Pembelajaran dalam kurikulum 2006 dilaksanakan melalui pendekatan kontekstual yang merupakan konsep belajar yang membantu guru mengaitkan antara materi yang diajarkan dengan situasi dunia nyata siswa dan mendorong siswa membuat hubungan antara pengetahuan yang dimiliki dengan penerapannya dalam kehidupan mereka sebagai anggota keluarga dan masyarakat (Sagala: 2005). Ada tujuh komponen utama pembelajaran yang didasari penerapan pembelajaran kontekstual di kelas, ketujuh komponen utama itu adalah konstruktivisme (Contructivism), bertanya (Questioning), menemukan (Inquary), masyarakat belajar (Learning Community), permodelan (Modelling), refleksi (Reflection), dan penilaian sebenarnya (Autentic Assesment) (Nurhadi: 2003).

Untuk menjawab permasalahan di atas maka dalam penelitian ini dikembangkan model pembelajaran dan perangkat model pembelajaran berupa suplemen buku ajar IPA SD berbasis bahan di lingkungan sekitar dengan pendekatan starter eksperimen. Model dan perangkat pembelajaran diharapkan akan meningkatkan aktivitas, ketrampilan proses IPA, minat dan sikap ilmiah, dan hasil belajar siswa.

Permasalahan dalam penelitian dirumuskan sebagai berikut: 1) Bagaimanakah langkahlangkah pengembangan model dan perangkat pembelajaran sehingga diperoleh suplemen buku ajar IPA SD berbasis bahan di lingkungan sekitar dengan pendekatan starter experimen? 2) Seberapa besar efektivitas dan keterandalan model dan perangkat pembelajaran yang telah dikembangkan? Tujuan penelitian yaitu: 1) menghasilkan suplemen buku ajar IPA SD berbasis bahan-bahan di lingkungan sekitar, 2) menguji efektivitas dan keterandalan model dan perangkat pembelajaran melalui pembelajaran di sekolah.

\section{Kajian Literatur}

IPA atau sains merupakan suatu kumpulan pengetahuan yang tersusun secara sistematis, dan dalam penggunaannya secara umum terbatas pada gejala gejala alam. Perkembangan IPA selanjutnya tidak hanya ditandai oleh adanya kumpulan fakta saja, tetapi juga ditandai oleh munculnya "metode ilmiah" (scientific methods) yang terwujud melalui suatu rangkaian "kerja ilmiah" (working scientifically), nilai dan "sikap ilmiah" (scientific attitudes). Sejalan dengan pengertian IPA tersebut, James B. Conant (dalam Jatmiko, 2004) mendefinisikan IPA sebagai suatu rangkaian konsep yang saling berkaitan dengan bagan-bagan konsep yang telah berkembang sebagai suatu hasil eksperimen dan observasi, yang bermanfaat untuk eksperimentasi dan observasi lebih lanjut.

Merujuk pada pengertian IPA di atas, maka hakikat IPA meliputi empat unsur, yaitu: 1) produk: berupa fakta, prinsip, teori, dan hukum; 2) proses: prosedur pemecahan masalah melalui metode ilmiah; metode ilmiah meliputi pengamat-an, penyusunan hipotesis, perancangan eksperi-men, percobaan atau penyelidikan, pengujian hipotesis melalui eksperimentasi; evaluasi, pengukuran, dan penarikan kesimpulan; 3) aplikasi: penerapan metode atau kerja ilmiah dan konsep IPA dalam kehidupan sehari-hari; 4) sikap: rasa ingin tahu tentang obyek, fenomena alam, makhluk hidup, serta hubungan sebab akibat yang menimbulkan masalah baru yang dapat dipecahkan melalui prosedur yang benar; sains bersifat open ended (Puskur Depdiknas: 2006). Ditinjau dari kurikulum 2006, mata pelajaran IPA memiliki beberapa komponen yaitu: 1) Ruang Lingkup Bahan Ajar; 2) Proses Pembelajaran, dan 3) Penilaian atau Assesmen.

Penilaian proses dan hasil belajar IPA menuntut teknik dan cara-cara penilaian yang lebih komprehensif. Di samping aspek hasil belajar yang dinilai harus menyeluruh yaitu aspek kognitif, afektif, dan psikomotorik, teknik penilaian dan instrumen penilaian seyogianya lebih bervariasi. Hasil belajar dapat dibedakan menjadi pengetahuan (knowledge), penalaran (reasoning), keterampilan (skills), hasil karya (product), dan afektif (affective). Adapun hasil belajar tersebut dapat diungkap atau dideteksi melalui beberapa cara atau teknik seperti: pilihan atau respons terbatas (selected response), assesmen esai (essay assessment), assesmen kinerja (performance assessment), dan komunikasi personal (personal communication).

Model pembelajaran starter eksperimen merupakan salah satu model penerapan pembe- 
lajaran kontekstual yang melatih dan mengajar siswa untuk belajar konsep IPA sama halnya dengan seorang ilmuwan IPA. Siswa belajar aktif dengan mengikuti tahap-tahap pembelajaran, dengan demikian siswa akan menemukan sendiri sesuai hasil yang diperoleh selama proses pembelajaran.

Pelaksanaan pembelajaran starter eksperimen menekankan pada kerja kooperatif/ kolaboratif. Model pembelajaran kooperatif merupakan salah satu model pembelajaran yang bermuara pada pendekatan konstruktivistik. Dalam pembelajaran kooperatif siswa belajar bersama, saling menyumbangkan fikiran dan bertanggung jawab terhadap pencapaian hasil belajar secara individu dan kelompok. Model pembelajaran ini berpandangan bahwa siswa akan lebih mudah menemukan dan memahami konsep-konsep yang sulit apabila mereka saling mendiskusikan konsep-konsep tersebut dengan teman sebayanya (Slavin, 1994). Berbagai hasil penelitian menunjukkan bahwa pembelajaran kooperatif merupakan strategi yang cukup efektif dalam pembelajaran. (Johnson: 1989, Slavin: 1994, Nur:1998, Tanrere: 2005, 2007, Wagiran: 2006).

Perubahan orientasi pembelajaran dari berpusat pada guru ke berpusat pada siswa menuntut pembelajaran berdasarkan aktivitas. Belajar berdasarkan aktivitas berarti bergerak aktif secara fisik ketika belajar, dengan memanfaatkan indera sebanyak mungkin, dan membuat seluruh tubuh/pikiran terlibat dalam proses belajar. Hal ini dapat dilakukan dengan melakukan pembelajaran SAVI (Meiyer: 2000) yang merupakan singkatan dari: Somasi: belajar dengan bergerak dan berbuat, Auditori: belajar dengan berbicara dan mendengar, Visual: belajar dengan mengamati dan menggambarkan, Intelektual: belajar dengan memecahkan masalah dan merenung. Belajar akan optimal apabila ke empat unsur SAVI ada dalam suatu pembelajaran. Eksperimen IPA berbasis bahan-bahan di lingkungan sekitar dikembangkan melalui model pembelajaran Starter Eksperimen dengan memperhatikan unsur-unsur SAVI dan dilakukan dengan metode ilmiah. Metode untuk menemukan jawaban secara ilmiah meliputi langkah-langkah sebagai berikut; tujuan, hipotesis, penelusuran informasi atau pustaka, percobaan, kesimpulan (Joice: 2003).

Studi pendahuluan yang telah dilakukan dan terkait dengan rancangan penelitian ini antara lain: 1) Kajian kurikulum KTSP IPA SD menunjukkan bahwa dalam Standar Kompetensi dan Kompetensi Dasar kurang menggali ketrampilan proses IPA; 2) studi pendahuluan ke beberapa sekolah dan konsultasi dengan guru menunjukkan bahwa pembelajaran masih berorintasi pada guru dimana masih dominan menggunakan metode ceramah; 3) penelitian Paledang (2003) menunjukkan penerapan pendekatan starter eksperimen dapat meningkatkan pemahaman konsep IPA siswa sekolah dasar; 4) penelitian Side (2005) menunjukkan penerapan pembelajaran starter eksperimen dapat meningkatkan aktivitas dan hasil belajar siswa SMP; 5) penelitian Jusniar (2006) menunjukkan pembelajaran starter eksperimen dengan setting kooperatif mampu meningkatkan pemahaman konsep siswa; 6) penelitian Tanrere (2007) menunjukkan bahwa model pembelajaran konstruktivistik realistik dengan setting kooperatif dapat meningkatkan kualitas pembelajaran antara lain peningkatan motivasi belajar, sikap, minat, kreativitas, keterampilan proses, dan hasil belajar siswa.

\section{Metodologi Penelitian}

Penelitian ini termasuk jenis penelitian pengembangan (Research and Development). Penelitian pengembangan merupakan metode penelitian yang digunakan untuk menghasilkan produk tertentu serta menguji keefektifan produk tersebut (Sugiyono:2006). Rancangan pengembangan dilakukan berdasarkan model pengembangan oleh Thiagarajan, dkk (1974) yang dikenal dengan " Four-D Model" yaitu define, design, develop, and disseminate.

Penelitian ini dilaksanakan dengan langkahlangkah sebagai berikut: 1) pendefinisian meliputi analisis kurikulum, kajian buku paket IPA SD, observasi lapangan, penentuan model pembelajaran; 2) perancangan meliputi penulisan model pembelajaran dan perangkat model pembelajaran meliputi panduan eksperimen, LKS dan alat evaluasi. Model pembelajaran dikembangkan berdasarkan pandangan konstruktivisme dengan penerapan pembelajaran Starter eksperimen 
seting kooperatif (Ibrahim:2000 dan Jusniar: 2006), panduan eksperimen dikembangkan mengacu pada jenis eksperimen yang dikembangkan dengan langkah-langkah metode ilmiah yang meliputi tujuan, hipotesis, penelusuran informasi atau pustaka, percobaan, kesimpulan (Joice: 2003 dan Virgina:1968), LKS dikembangkan berdasarkan jenis eksperimen, dan alat evaluasi dikembangkan berdasarkan rubrik penilaian pembelajaran dan eksperimen (Parratore: 2005) untuk mengukur kinerja dan pencapaian tujuan pembelajaran. Penilaian model dan perangkat model pembelajaran oleh tim ahli (validator), revisi model pembelajaran dan perangkat model pembelajaran; 3) pengembangan melalui ujicoba model dan perangkat model pembelajaran dan analisis hasil ujicoba di tiga SD Negeri Kota Enrekang; dan 4) desiminasi meliputi sosialisasi secara luas model dan perangkat model pembelajaran.

Pada tahap pendefinisian, tim peneliti mengadakan analisis kurikulum, analisis buku paket, observasi lapangan tentang pembelajaran IPA terutama situasi yang dihadapi guru, hambatanhambatan dalam mengajar baik menyangkut materi bahan ajar, konsep-konsep eksperimen IPA yang dikembangkan, pelaksanaan eksperimen, karakteristik belajar siswa. Pada tahap perancangan mencakup penentuan format model dan perangkat pembelajaran, penulisan panduan eksperimen dan ujicoba panduan eksperimen di Laboratorium Kimia FMIPA UNM, penulisan LKS dan alat evaluasi. Pada tahap pengembangan, diawali dengan evaluasi model dan perangkat model pembelajaran oleh tim ahli pendidikan IPA dan Teknologi Pendidikan. Berdasarkan hasil evaluasi dilakukan perbaikan-perbaikan dan penyempurnaan model dan perangkat model pembelajaran. Selanjutnya dilakukan ujicoba model dan perangkat model pembelajaran di sekolah. Dari hasil evaluasi ujicoba dan saran-saran validator diadakan kembali perbaikan-perbaikan terhadap model dan perangkat model pembelajaran. Pada tahap desiminasi dilakukan implementasi dan sosialisasi secara luas model dan perangkat model pembelajaran pada guru-guru SD di Kabupaten Enrekang.

Pengumpulan data dilakukan dengan menggunakan berbagai instrumen pengumpul data sebagai berikut: 1) Lembar Observasi Aktivitas
Siswa: Instrumen ini digunakan untuk mengumpulkan data mengenai aktivitas siswa mengikuti pembelajaran dan aktivitas melaksanakan eksperimen; 2)Lembar Observasi Aktivitas Guru: Instrumen ini digunakan untuk mengumpulkan data mengenai aktivitas guru melaksanakan pembelajaran dan aktivitas membimbing eksperimen; 3) Lembar Observasi Minat dan Sikap IImiah) 4) Lembar Observasi Keterampilan Proses IPA; dan 5) Tes hasil belajar: Instrumen ini digunakan untuk mengetahui hasil belajar siswa yang dilakukan pada akhir ujicoba.

Data yang terkumpul dari hasil observasi aktivitas guru dan aktivitas siswa, sikap ilmiah dan keterampilan proses, serta hasil belajar siswa dianalisis secara deskriptif kuantitatif melalui analisis persentasi.

Indikator pencapaian tujun meliputi indikator kualitas model pembelajaran dan indikator kinerja melalui penelitian pra eksperimen.

Indikator kualitas model pembelajaran melalui validator tim akhli: kesesuaian antara perangkat pembelajaran dengan silabus IPA SD, kesesuaian antara panduan eksperimen dengan skenario pembelajaran, kesesuaian antara alat evaluasi dengan skenario pembelajaran, tingkat ketersediaan peralatan dan bahan-bahan eksperimen,

Indikator kinerja ujicoba penelitian yaitu: a) Terjadinya perubahan orientasi pembelajaran yang lebih berpusat pada siswa dimana guru lebih banyak berfungsi sebagai fasilitator dan mediator dalam pembelajaran; b) Minat dan sikap ilmiah siswa termasuk katagori baik; c) Keterampilan proses siswa termasuk katagori baik; dan d) Minimal $75 \%$ siswa mencapai ketuntasan belajar sesuai sesuai dengan tingkat ketuntasan yang ditetapkan sekolah yaitu 70

\section{Hasil Penelitian dan Pembahasan}

Langkah-langkah pengembangan penelitian meliputi: 1) Pendefinisian yang meliputi: Observasi lapangan tentang pembelajaran IPA SD di Kabupaten Enrekang dan mengidentifikasi situasi yang dihadapi guru, hambatan-hambatan dalam mengajar baik menyangkut materi bahan ajar, konsep-konsep eksperimen IPA yang dikembangkan, pelaksanaan eksperimen, karakteristik siswa; 2) perancangan meliputi: analisis kurikulum, mengkaji materi dan pengembangan jenis 
eksperimen yang mungkin dikembangkan; 3) pengembangan meliputi: penulisan skenario pembelajaran, penulisan panduan eksperimen, penulisan LKS dan alat evaluasi; 4) validasi tim akhli; 5) revisi model dan perangkat pembelajaran, (6) Ujicoba lapangan penelitian pra eksperimen.

\section{Observasi Awal}

Hasil observasi dan wawancara dengan guruguru IPA di tiga sekolah yang mewakili SD Kabupaten Enrekang yaitu SDN 116 Enrekang, SDN 104 Tontonan, SDN 105 Baraka yaitu sebagai berikut: a) Pengembangan program tahunan, program semester telah ada dan disusun bersama bidang studi lainnya berdasarkan Kurikulum Tingkat Satuan Pendidikan (KTSP. Pelaksanaan remidial dilakukan setelah tes unit atau ujian blok; b) Pengembangan Sillabus yang digunakan di Kabupaten Enre-kang masih bervariasi, ada yang langsung berpedoman pada silabus KTSP yang dibuat oleh Badan Standar Nasional Pendidikan (BNSP) dan ada Berdasar Standar Isi yang ditetapkan DIKNAS kemudian disusun silabus bersama guru IPA ditingkat Kecamatan, selanjutnya di KKG kan kemudian dipakai bersama di tingkat Kecamatan. Sillabus yang digunakan dianggap layak karena mengacu pada BNSP dan dibuat secara bersama-sama dan di KKG kan. Indikator perubahan pengetahuan, sikap dan keterampilan dijabarkan dari isi; c) Pengembangan RPP yang digunakan oleh guru adalah RPP yang disusun sendiri oleh masing-masing guru IPA yang mengacu pada RPP yang telah disusun oleh Balai Pustaka Dharma Bhakti yang diperjual belikan. Pelaksanaan pembelajaran di kelas ada kalanya tidak sesuai antara uraian yang ada dalam RPP. Secara keseluruhan RPP yang dibuat oleh guru cukup layak untuk digunakan; d) Pelaksanaan Pembelajaran materi guru-guru IPA di Enrekang adalah bervariasi tergantung dari pengalaman mengajar dan tingkat pendidikannya. Guru-guru dengan tingkat pendidikan PGSD rata-rata masih merasakan kesulitan dalam beberapa topik antara lain: energi alternatif, struktur bumi dan matahari dan lain-lain. Guru-guru dengan tingkat pendidikan dan pengalaman lebih tinggi kurang mengalami kesulitan dalam materi, namun merasa perlu adanya penyegaran. Metode pembelajaran yang sering digunakan oleh guru adalah ceramah, diskusi dan observasi. Eksperimen sudah dilakukan namun hanya terbatas pada observasi karena keterbatasan waktu. Evaluasi yang dilakukan berupa evaluasi tulisan, lisan, maupun keterampilan percobaan/observasi; e) Karakteristik belajar siswa, meliputi: (1) Sikap siswa terhadap IPA adalah cukup positif; (2) Minat dan aktivitas belajar kimia siswa adalah cukup baik; (3) Aktivitas belajar meningkat terutama jika ada percobaan; f) Problem-problem yang dihadapi dalam pembelajaran IPA adalah sebagai berikut: (1) Alokasi waktu yang dirasakan kurang; (2) Contoh-contoh dalam buku tidak dapat diihat langsung oleh siswa; (3) Beberapa percobaan dianggap sulit oleh guru, misalnya pembuktian bahwa fotosintesis menghasilkan amilum; dan (4) Kesulitan siswa merumuskan kesimpulan dalam menyusun laporan percobaan; g) Problemproblem yang dihadapi dalam eksperimen IPA adalah sebagai berikut: (1) Beberapa percobaan terkendala oleh alat dan bahan; (2)Kesulitan siswa dalam membuat laporan hasil percobaan; (3) Percobaan sering gagal sehingga perlu diulang-ulang; (4) Siswa sering salah observasi karena tidak ada panduan; (5) Kurangnya waktu yang tersedia; h) Saran-saran untuk peningkatan kualitas pembelajaran IPA, yaitu: (1) Perlu ada bantuan buku panduan pelaksanaan berbagai percobaan; (2) Perlu pelatihan/penyegaran dalam: Teknik pembelajaran, pendalaman materi IPA, pembuatan alat peraga, alat percobaan.

\section{Perancangan Model dan Perangkat Pembelajaran}

Berdasarkan kajian kurikulum, Standar Kompetensi dan Kompetensi Dasar IPA SD maka dikembangkan model pembelajaran dan perangkat pembelajaran yang terdiri, panduan eksperimen, LKS, dan alat evaluasi.

Hasil pengembangan model pembelajaran adalah sintaks sebagai berikut:

Langkah 1: Pendahuluan: Menetapkan dan menjelaskan tujuan pembelajaran: (1) Menjelaskan kepada siswa proses kooperatif yang akan digunakan, tujuan pembelajaran, dan mengaitkan dengan pengetahuan awal siswa; (2) Menetapkan tingkah laku 
dan interaksi antara siswa yang diharapkan

Langkah 2: Mengatur siswa ke dalam kelompok belajar: 1) Mengatur kelompokkelompok yang terdiri dari 4 atau 5 orang secara heterogen berdasarkan kemampuan akademik, jenis kelamin, dan latar belakang keluarga; 2) Mengatur peran setiap anggota kelompok dalam kelompoknya

Langkah 3: Pengembangan pembelajaran: 1) Percobaan awal; pembelajaran diawali dengan melakukan percobaan yang didemonstrasikan guru atau dengan mengamati fenomena alam. Demonstrasi menampilkan masalahmasalah berkaitan dengan materi IPA yang akan dipelajari; 2) Pengamatan; merupakan kegiatan siswa pada saat guru melakukan percobaan. Siswa diharapkan untuk mengamati dan mencatat peristiwa tersebut; 3) Hipotesis (dugaan awal), siswa dapat merumuskan hipotesis sementara berdasarkan hasil pengamatannya; 4) Percobaan pengujian (verivikasi); kegiatan untuk membuktikan kebenaran dari dugaan awal yang telah dirumuskan dan dilakukan melalui kerja kelompok. Siswa diharapkan merumuskan hasil percobaan dan membuat kesimpulan, selanjutnya dapat dilaporkan hasilnya; 5) Aplikasi konsep, setelah siswa merumuskan dan menemukan konsep, hasilnya diaplikasikan dalam kehidupannya. Kegiatan ini merupakan pemantapan konsep yang telah dipelajari.

Langkah 4: Membantu siswa bekerja dan belajar dalam kelompoknya

Langkah 5: Evaluasi, baik individu maupun kelompok

Langkah 6: Memberikan penghargaan pada kelompok. Penghargaan untuk kelompok bisa berupa benda, status, sanjungan/pujian, dan sebagainya.

Hasil pengembangan perangkat model pembelajaran yang berisikan Panduan Eksperi- men, Lembaran Kerja Siswa, dan alat evaluasi menghasilkan tiga buah buku suplemen IPA SD yaitu "Terampil Sains" Eksperimen IPA Berbasis Bahan-bahan Di Lingkungan Sekitar untuk kelas 4, 5, dan 6 .

\section{Validasi Model dan Perangkat Pembelajaran}

Validasi model dan perangkat pembelajaran diukur berdasarkan indikator sebagai berikut:

Kriteria Valid:

$$
\begin{array}{ll}
80-100 \% & =\text { Valid } \\
60-79 \% & =\text { cukup valid } \\
<60 & =\text { tidak valid }
\end{array}
$$

Hasil validasi perangkat pembelajaran terlihat pada Tabel 1 .

\section{Keperaktisan Model dan Perangkat Pembelajaran}

Berdasarkan hasil wawancara dengan guru mitra dan siswa tempat ujicoba disimpulkan sebagai berikut: a) Model pembelajaran yang diperkenalkan pada guru merupakan hal yang baru namun penerapan model pembelajaran mudah dipahami karena terkait dengan bahan bahan yang ada di lingkungan sekitar; b) Guru mempunyai kemampuan menjelaskan model yang akan digunakan; c) Kemampuan guru melakukan percobaan awal cukup namun untuk merancang percobaan awal memerlukan persiapan dari guru karena tidak ada dalam perangkat model pembelajaran; d) Panduan eksperimen dapat dipahami dengan baik oleh guru; e) LKS yang digunakan mudah dilaksanakan namun diperlukan ujicoba sebelum eksperimen dilakuan oleh siswa; dan f) Alat evaluasi yang digunakan dapat mengukur aktivitas siswa.

Untuk kelancaran penerapan model dan perangkat pembelajaran, guru menyarankan adanya buku khusus petunjuk guru yang berisi ekspeimen awal, hasil eksperimen, dan kesimpulan yang diperoleh dari suatu eksperimen.

Nilai Rata-rata: 1) Model pembelajaran = 88,40 termasuk katagori Valid; 2) Perangkat pembelajaran $=84,66$ termasuk katagori Valid

Berdasarkan hasil wawancara dengan siwa diperoleh hal-hal sebagai berikut: a) Siswa senang mengikuti pembelajaran; b) Bahan-bahan yang digunakan mudah diperoleh di lingkungan sekitar; c) Kerja kelompok secara kooperatif 
Tabel 1. Hasil validasi model dan perangkat pembelajaran dari tiga validator

\begin{tabular}{|c|c|c|c|}
\hline No. & Aspek yang Dinilai & Rata-rata & Keterangan \\
\hline 1 & 2 & 3 & 4 \\
\hline & MODEL PEMBELAJARAN & & \\
\hline 1. & Kesesuaian model dengan KTSP & 91,75 & Valid \\
\hline 2. & Kejelasan langkah-langah dalam model & 83,25 & Valid \\
\hline 3. & Kemampuan model untuk meningkatkan aktivitas siswa & 91,75 & Valid \\
\hline 4. & Kemudahan model untuk dilaksanakan & 91,75 & Valid \\
\hline 5. & Kesesuaian model dengan tingkat perkembangan siswa & 83,25 & Valid \\
\hline & PERANGKAT EKSPERIMEN & & \\
\hline 1. & Kesesuaian komponen BAB dengan Kompetensi Dasar & 83,25 & Valid \\
\hline 2. & $\begin{array}{l}\text { Kesesuaian bahasan sub-sub bab dengan Standar } \\
\text { Kompetensi }\end{array}$ & 91,75 & Valid \\
\hline 3. & Kesesuain topik dengan sub bab & 91,75 & Valid \\
\hline 4. & Kesesuaian tujuan dengan topik & 83,25 & Valid \\
\hline 5. & Kejelasan rumusan tujuan & 83,25 & Valid \\
\hline 6. & Kejelasan bahasa dalam rumusan tujuan & 75,00 & Cukup Valid \\
\hline 7 & Kelengkapan panduan eksperimen & 83,25 & Valid \\
\hline 8. & Kejelasan bahasa dalam panduan eksperimen & 83,25 & Valid \\
\hline 9. & Kemudahan panduan eksperimen untuk dilakukan & 83.25 & Valid \\
\hline 10. & Kemudahan panduan eksperimen untuk dipahami & 91,75 & Valid \\
\hline 11. & Sistematika panduan eksperimen & 91,75 & Valid \\
\hline 12. & Kemenarikan eksperimen & 75.00 & Cukup Valid \\
\hline 13. & Ketersediaan alat yang dibutuhkan dalam eksperimen & 100 & Valid \\
\hline 14. & Ketersediaan bahan yang dibutuhkan dalam eksperimen & 100 & Valid \\
\hline 15. & Kesesuaian antara LKS dengan panduan eksperimen & 83,25 & Valid \\
\hline 16. & Kelengkapan LKS & 83,25 & Valid \\
\hline 17. & Kejelasan bahasa dalam LKS & 83,25 & Valid \\
\hline 18. & Kemudahan LKS untuk dilakukan & 91,75 & Valid \\
\hline 19. & Kemudahan LKS untuk dipahami & 83,25 & Valid \\
\hline 20. & Sistimatika LKS & 91,75 & Valid \\
\hline 21. & Kesesuaian antara alat evaluasi dengan LKS & 75,00 & Cukup Valid \\
\hline 22. & Kelengkapan alat evaluasi & 75,00 & Cukup Valid \\
\hline 23. & Kemudahan alat evaluasi untuk digunakan & 83,25 & Valid \\
\hline 24. & Kejelasan bahasa alat evaluasi & 83,25 & Valid \\
\hline 25. & $\begin{array}{l}\text { Kesesuaian antara panduan eksperimen, LKS dan alat } \\
\text { evaluasi }\end{array}$ & 66,75 & Cukup Valid \\
\hline
\end{tabular}

membantu dalam memahami pelajaran; d) Panduan eksperimen mudah dipahami oleh siswa; e) Lembar kerja siswa mudah digunakan; f) Siswa memerlukan bimbingan dalam menarik kesimpulan

\section{Efektivitas Model Pembelajaran}

Rata-rata aktivitas guru adalah $85,38 \%$ termasuk katagori tinggi. Dari 26 item aktivitas guru, 69,23\% termasuk katagori tinggi dan 30,77 termasuk katagori sedang. Rata-rata aktivitas siswa adalah $72,32 \%$ termasuk katagori sedang. Dari 20 item aktivitas siswa, $50 \%$ termasuk katagori tinggi, $45 \%$ termasuk katagori sedang, dan $5 \%$ termasuk katagori rendah.

Rata-rata keterampilan proses sains siswa adalah $87 \%$ termasuk katagori tinggi. Dari 10 item keterampilan proses siswa yang diamati, $80 \%$ termasuk katagori tinggi, dan 20\% termasuk katagori sedang. Rata-rata sikap dan minat siswa yang diamati adalah 93\% termasuk katagori tinggi. Dari 10 item sikap dan minat siswa yang diamati $100 \%$ termasuk katagori tinggi. Dari data hasil belajar siswa, terdapat $87,5 \%$ siswa mencapai ketuntasan belajar sesuai dengan standar ketuntasan 70 .

Walaupun penerapan model pembelajaran memperlihatkan hasil yang baik, namum beberapa hal yang menjadi keluhan guru dalam pelaksanaan model pembelajaran ini antara lain: 1) waktu yang digunakan dalam proses pembelajaran di kelas rata-rata lebih lama dibandingkan dengan waktu yang digunakan guru pada sebelumnya; 2) guru memerlukan waktu yang relatif banyak untuk mempersiapkan pembelajaran. 


\section{Simpulan dan Saran Simpulan}

Hasil pengembangan adalah model pembelajaran dan perangkat pembelajaran berupa buku "Terampil Sains" Eksperimen IPA Berbasis Bahanbahan Di Lingkungan Sekitar untuk kelas 4, 5, dan 6. Penerapan model dan perangkat pembelajaran yang dikembangkan dalam penelitian ini akan membuka wawasan siswa tentang eksperimen atau pengamatan fenomena alam yang akan dilakukan. Eksperimen menjadi menarik karena bahan-bahan dan alat yang digunakan cukup murah bahkan menggunakan bahan bahan bekas yang ada di lingkungan sekitar.

Pelaksanaan eksperimen atau pengamatan fenomena alam sekitar dengan menggunakan perangkat pembelajaran (panduan eksperimen, LKS, dan alat evaluasi) yang dikembangkan akan: 1) meningkatkan aktivitas siswa yang berakibat terhadap perubahan orientasi pembelajaran menjadi berpusat pada siswa; 2) mendorong peningkatan sikap ilmiah yaitu kedisiplinan, kerjasama, kejujuran dan rasa tanggung jawab atas tugas yang dilakukan; 3 ) mendorong peningkatan keterampilan proses sains antara lain mengamati, mengumpulkan data yang relevan, mengelompokkan, membandingkan, menafsirkan, menarik kesimpulan, merencanakan prosedur, menggunakan alat dan bahan; dan 4) meningkatkan hasil belajar siswa.

\section{Saran}

Berdasarkan hasil pengembangan yang dilakukan disarankan:

Untuk menunjang pelaksanaan kurikulum KTSP, guru seharusnya menerapkan pembelajaran yang berpusat pada siswa melalui pembelajaran aktif berbasis kontekstual. Salah satu diantaranya adalah model pembelajaran starter eksperimen berbasis bahan-bahan di lingkungan sekitar

Penggunaan buku "Terampil Sains" Eksperimen IPA SD Berbasis Bahan-bahan Di Lingungan Sekitar sebaiknya ditunjang oleh buku paket IPA SD sehingga memudahkan dalam menarik kesimpulan dari eksperimen atau pengamat-an fenomena alam yang dilakukan.

\section{Pustaka Acuan}

Ibrahim, Muslimin. 2000. Pembelajaran Kooperatif. Surabaya: Universitas Negeri Surabaya

Jatmiko, B. 2004. Hakikat Pembelajaran IPA. Semlok bagi Dosen, Mahasiswa, Guru-guru SD, SMP dan SMA se Bali. Singaraja: FMIPA IKIP Negeri.

Johnson, D.W., dan Johnson, R.T., 1989. Cooperative and Competitive: Theory and Research, Edina, MN: Interaction Book Co.

Joice, Van Cleave. 2003. A+ Projects in Chemistry, 2003. Terjemahan Wasi Dewanto, Bandung: Penerbit Pakar Raya

Jusniar. 2006. Pengaruh Pendekatan Starter Eksperimen dengan Setting Kooperatif terhadap pemaaman konsep IPA Kimia Sswa SMP. Laporan Hasil Penelitian. Lemlit UNM

Meiyer, Dave. 2000. The Accelerated Learning Handbook. Terjemahan Rahmani Astuti. Bandung: Penerbit Kaifa.

Nur, Muh. 1998. Pendekatan-Pendekatan Konstruktivis dalam Pembelajaran. Surabaya: IKIP Surabaya.

Nurhadi. 2003. Pembelajaran Kontekstual dan Penerapannya dalam KBK. Malang:

Penerbit Universitas Negeri Malang

Paledang, Francisca. 2003. Pengaruh pendekatan starter eksperimen terhadap pemahaman konsep IPA Siswa Sekolah Dasar. Jurnal Teknologi Pembelajaran Tn. 11, No. 2, Oktober 2003. Malang: UM

Parratore, Phil. 2005. Hand-On Science for Active Learning Classroom. Terjemahan Mike Gembirasari. Bandung: Penerbit Nuansa

Puskur Depdiknas. 2006. Pengetahuan Alam (http://www.puskur. net/nc/si/sd/ PengetahuanAlam. Diakses tanggal 20 Desember 2008 
Sagala, Syaiful. 2005. Konsep dan Makna Pembelajaran. Bandung. Alfabeta

Side, Sumiati. dkk. 2005. Penerapan Pendekatan Starter Eksperimen untuk Meningkatkan Kualitas Pembelajaran Kimia di SMP. Makassar. Lembaga Penelitian UNM

Slavin, R.E. 1994. Educational Psychology, Theory and Practice. Fourth Edition, Massachusetts: Allyn and Bacon Publisher.

Sugiyono. 2006. Metode Penelitian Pendidikan Pendekatan Kuantitatif, Kualitatif, dan R\&D. Bandung: Alfabeta

Tanrere, Munir. 2005. Implementasi Model Pembelajaran Kooperatif Tipe STAD untuk Meningkatkan Kualitas Proses dan Hasil Belajar Siswa. Jurnal Ilmu Kependidikan LPMP Sul-Sel Vol. 2, Nomor 3, Desember 2005.

Tanrere, Munir. 2007. Kajian Model Pembelajaran Konstruktivistik Realistik dengan Setting kooperatf dan dampaknya terhadap perkembangan konsep siswa. Laporan hasil penelitian, Makassar: Lemlit UNM

Thiagarajan, S., Doroty S. Semmel, and Melvyn I. Semmel. 1974. Instructional Development for Training Teachers of Exceptional Children, A Sourcebook, Bloomington: Centre for Innovation on Teaching the Handicapped.

Virgina L. Mullin. 1968. Chemistry Experiments for Children. New York: Dover Publications.

Wagiran. 2006. Meningkatkan Keaktifan Mahasiswa dan Reduksi Miskonsepsi Melalui Pembelajaran Konstruktivistik Model Kooperatif Berbantuan Modul. Jurnal IImu Pendidikan. Jilid 13, Nomor 1, Februari 2006. 